\title{
PREWRITING ACTIVITIES USING ASSISTED- TECHNOLOGY IN EFL JOURNALISM: A NEEDS ANALYSIS
}

\author{
Dwi Sloria Suharti ${ }^{1}$, Eka Ugi Sutikno², Hani Dewi Aries Santi ${ }^{3}$ \\ ${ }^{1}$ Universitas Muhammadiyah Tangerang \\ ${ }^{2}$ Universitas Muhammadiyah Tangerang \\ ${ }^{3}$ Universitas Esa Unggul \\ 11dwisloria@umt.ac.id, 2ekaugisutikno@umt.ac.id, ${ }^{3}$ hani.dewi@esaunggul.ac.id
}

\begin{abstract}
Analysis of the needs is an imperative pace for curriculum developers in different subjects, including assisted-technology in prewriting activities in EFL Journalism. Needs are required to examine the assisted-technology demanded while EFL learners applied prewriting activities. This study aimed to study assisted-technology necessities in EFL students' prewriting activities at a private university in Indonesia. The study investigated the needs of assisted technology in prewriting activities in EFL Journalism learning. A qualitative description has been developed. Seventy-two students completed the questionnaires, and several students were also interviewed. The result revealed that students are in needs, lacks, and wants assisted-technology in prewriting activities. This study suggests that teachers and universities periodically carry out a needs analysis to develop a curriculum and teaching strategies for all of these reflective needs.
\end{abstract}

Keywords: Assisted-Technology In Language Learning, EFL Writing, Prewriting Activities, Needs Analysis

\section{INTRODUCTION}

Various studies have been carried out on learners' roles in second and foreign language learning, which have influenced language teaching towards more learner-centered techniques (Nunan, 2003; Brown, 2007). Thus, the needs and expectations of learners have recently gained extraordinary potential. According to Brown (2007), the needs analysis is the basis for developing a curriculum that meets a specific set of students' learning needs. However, despite its value in setting targets for learners, teacher educators often overlook needs analysis and neglect it. Needs Analysis (NA) is a crucial component when an educator is assigned to develop a syllabus, instructional materials, and techniques for a specific course, such as EFL Journalism writing. The outcomes of needs analysis must be useful for curriculum design. The target needs (what the learners need to do in the target situation) is required to achieve learning outcomes (Nation \& Macalister, 2010).

In practice, writing is a language skill that is rarely in demand because of students' difficulties. Various kinds of approaches have been promoted by teachers or teachers to overcome these difficulties. There are three main approaches to writing: the process approach, the product approach, and the genre text approach (Al-Gharabally, 2015). Based on the curriculum and syllabus, secondary schools in Indonesia, English writing and reading already use a genre approach. However, at universities, teachers can use a variety of approaches and strategies.

One important strategy is the teacher's role in motivating their students to work harder and guide them to improve their English by telling them the effects of using a direct translation of their first language. Teachers should encourage students to think in English so that their mother 
tongue or first language does not appear, so grammatical errors do not occur. According to Abdullah (2013), 96 percent of students committed such errors using the simple present tense. Misconception factor errors due to regularization are the most frequently produced errors. The inherent difficulties of learning English, overgeneralization, and lack of English exposure contribute to students' errors.

Most EFL students found several types of syntactic errors written by students in writing practice, namely writing the correct sentence structure. These syntactic errors are the compatibility of the subject-verb, article, possessive, pronoun, verb 'to be,' simple present tense, simple past tense, and present continuous. A previous study established eight forms of syntactic errors that students wrote in writing. Errors include subject-verb agreement, articles, possessives, pronouns, the verb 'to be,' simple present tense, simple past tense, and continuous present. Students appear to unintentionally translate their L1 rules (Bahasa Melayu) into English (English). They have difficulty building simple sentences in their L2 writings. Recommendation for Malaysian language teachers should identify the change between Bahasa Melayu and English. Teachers should consider using a grammar-translation method for learners. More research is needed to analyze secondary and primary multicultural students ' written errors in Malaysia to identify whether Bahasa Melayu harms English (Singh \& Maniam, 2020).

Moreover, regarding the intercultural dimension in language teaching, teachers who teach have to face more obstacles (Álvarez, 2020). Also, many important details go unnoticed by the teacher/lecturer in regular language learning classes, thereby enlarging the visible images and behavior patterns while unintentionally missing out on many details that are thought to be a consequence of a better understanding of what lies on the surface. Such is the case with the role of group dynamics in a Foreign Language Learning (FLL) environment, which is handled little by little, contrary to the attention it has garnered in sociology's social sciences (Ben Maad \& Saadi, 2020).

The determining factor for learning English as a Foreign Language (EFL) in content and language is the integrated learning ability for learning English. It is the beliefs of students' use of the EFL Language in class. The international orientation, which is considered to include a general interest in other languages and cultures, a sense of identification with speakers of the target language, and a desire to use the target language for international communication, studies, and work, is also essential learning EFL language factor. Besides, English's effects on learners' daily lives, especially in the media, are often seen as supporting young people's L2 English skills (Goris et al., 2020).

A big problem for students is that they have very little interest in writing English, but it is essential to meet their educational needs. It may be due to their disappointment in losing motivation to express themselves through writing (Muslim, 2014; Abderraouf, 2016). Zhiyong et al. (2020) believed that college EFL teachers should frequently change their teaching plans to find the best address students' needs. The teachers should provide opportunities to engage students in activities to enhance their ability to use English. Therefore, students need a writing strategy to start writing English.

Some experts added that assisted technology facilitates effective language-classroom teaching. These include computers/gadgets, fast internet connections, and stable platforms - advanced instructor experience and how these resources help language classes (Troudi \& A-Mahrooqi, 2014). EFL teaching-learning ran online in the Pandemic COVID 19 age (Atmojo \& Nugroho, 
2020). EFL teaching-learning assisted technology becomes an immediate need. Using Assisted Technology to teach English writing to university-level EFL students is not a new venture in TEFL. However, Indonesia still rarely applies to this learning process. To fill that space, the researchers analyzed needs analysis on assisted technology in prewriting activities EFL Journalism writing learners and recognized the assisted technology/tools or applications used, benefits, and constraints.

\section{Literature review}

An essential and significant influence on language is the writing process. There are many variations on the process approach, and it is recognized that several writing stages are prewriting, compiling, giving, receiving feedback, and revising. English writing teachers need strategies to help students in their initial anxiety, start planning their ideas, and start writing (Weigle, 2014). This planning or prewriting gives EFL learners more opportunities to consider the meaning of the message being written and the language used to convey the message. EFL writers got the idea to start writing with a plan. These plans lead him to the writing process, then write it down well. In order, plans assist EFL writers in developing an appropriate and communicable idea or message in their writing (Servati, 2012).

Teachers' flexibility in using these approaches and strategies can be used by teachers to apply the strategies they think are more effective. In addition, Teachers can take advantage of developing technology as an additional way to attract students' attention to improve their writing skills. Assisted Technology is one-way teachers can teach to help learners learn English language skills, mainly EFL writing. Assisted Technology supports devices or applications such as text-to-speech software, word-processing programs, voice-recognition software, and organizing ideas software (Engstrom, 2005). The research community shows a significant correlation between critical thinking and creativity when a Digital Mind Mapping is integrated into Problem Based Learning (Problem Based Task). Besides, it was also found that both variables can be empowered simultaneously in the classroom, and thus simultaneous evaluation can be carried out for critical thinking and creativity. It is highly recommended that future researchers consider other variables that can also influence students' critical thinking and creativity (Hidayati et al., 2019).

Using an online platform helps increase student interest in learning a foreign language such as Kahoot, Blogging, Flipped classroom, and Google Classroom. Sartini (2020) believed that the Kahoot quiz greatly affected the vocabulary and terminology mastery of the Maritime English context. It promoted merchant mariner's smooth oral reproduction. Online gamification learning with technology-based learning will provide a robust alternative teaching approach to draw attention from marines. It trains marines for skilled human capital in a sophisticated digital age.

Indonesian EFL adult students found the use of online blogging to develop their writing skills. Students indicated that daily posting and commenting on Blogger helped boost audience writing fluency and awareness. The research was focused on students' expectations, and it is essential to perform a study examining whether these self-report benefits represent the real condition of students (Fithriani et al., 2019). Eyercİ \& ÇİMEN (2017) also reported that EFL writing teachers could incorporate blogging into their routine to attract students ' attention. Researchers hope teachers in Turkey will be inspired to try blogging as a teaching/learning method as they have gained worldwide popularity.

Moreover, Zou (2020) found that teachers accepted self-learning as part of the flipped classroom. Students showed a less favorable attitude, and some did not understand. The results 
for primary school students were not as positive as for university students. Fonseca \& Peralta (2019) revealed that students and ICTs to practice the language outside the classroom are strong indications they are becoming more autonomous learners. Introducing Google Classroom helped students improve their writing skills in an engaging, autonomous, and collaborative manner.

Some experts added that Assisted Technology supports the success of teaching in the language classroom. These technologies include the availability of computers/gadgets, fast internet connections, and secure platforms. Also, advanced teacher expertise and training on how these technologies support teaching in these language classes (Pirani, 2004; O'Neill, \& O'Donoghue, 2004; Baylor \& Ritchie, 2002 as cited in Troudi \& A-Mahrooqi, 2014).

\section{Previous research}

Prewriting, compilation, writing (first draft), response, revision, editing, posting, and evaluation steps in the writing process. Prewriting is defined as a structured activity to provide motivation, content, fluency, and language practices such as structured language practice, reading, films, discussions, brainstorming, webbing, outlining, as believed by Weigle (2014).

Prewriting activities can generate ideas, encourage thinking, and help students to find out what ideas they want to write and how to write them. These activities can be carried out in pairs, groups, or individually working. Various examples of prewriting activities: brainstorming, debate, interviews, use of pictures, outlines, lectures, or oral reading (Dwivedi \& Chakravarthy, 2015). In this study, the prewriting researcher's activity was brainstorming or outlining (Weigle, 2014; Dwivedi \& Chakravarthy, 2015). They are starting writing ideas before EFL students/learners is a technique or activity. Ideas finding is based on an EFL writing teacher theme.

Digital technologies will provide teachers and students with new mobile tools to learn the language efficiently. Under the Assisted technology Language Learning (TALL) mono umbrella, numerous options have emerged over the last 15 years of English language learning. The latest among numerous electronic gadgets that virtually affected all aspects of human life are Internet-skilled smartphones (Ahmad, 2016).

Research on the use of Assisted Technology is increasingly growing (Darmi \& Albion, 2014). Growing concern from educators and researchers that are learning difficulties in EFL writing. Ariyanti \& Fitriana (2017) reported that Widya Gama Mahakam University's fourth-semester students have write-essay challenges. Additional credits for English writing and grammar lessons may be contributed to deep understanding. Also, EFL teachers admit that dealing with students with writing difficulties is challenging. Students could be unmotivated because they know their difficulties. Becoming English teachers could benefit from observing students ' attitudes. Study attitudes towards writing in English will be insightful (Solagha, 2013).

Explaining a single item followed by assignments and exercises has a significant impact on helping EFL students improve their writing. The study has shown the strategies' effectiveness: Focusing on dividing students into groups and building cooperation. Creating challenges among students and offering a prize for the best group. Using the internet to help students improved their EFL writing (Muslim, 2014). EFL teachers must use an instructional design approach to find the required outcomes, set learning objectives and select the technology best suited to those learning objectives. We must use any viable meta-analysis platform to determine its most effective technology attributes (Marek, 2014).

Computer-assisted teaching has been shown to promote learning in several ways. Computers may be used to teach English-language students in core academic subjects. EFL students need 
more opportunities to expand their English skills. Home participation is essential to expanding what is achieved at school (Green, 2005). Web 2.0 and 3.0 provide endless opportunities for novelties, development, and progress. Long before the e-learning period, Plato (428 BC-348 BC) said: "In the far future, our grandchildren will build a new equivalent of our classrooms." Eventually, a student-centered approach focused on individualization, improving student motivation and responsibility can benefit (Mullamaa, 2006). Thus, ICT solutions may support various classroom activities, group-work and pair-work assignments, independent work, student-centered learning implementation.

ICTs can provide valuable tools to help learners access vast knowledge resources, collaborate with others, consult experts, exchange knowledge, and solve complex issues (Khvilon \& Patru, 2002). Technology can be an inevitable tool for educators and students because it can offer easy access and timeliness and provide EFL learners' different experiences. Ultimately, through Assisted Technology with various EFL learners' applications, both online and offline, it can help to access lessons and information from anywhere and anytime. However, Tabari \& Tabari (2014) reported that EFL teachers also have no high-quality, curriculum-based digital course materials. ICT programs such as computer-assisted language learning (CALL) cannot be implemented due to the curriculum's restricted use.

Conversely, EFL teaching-learning ran online in the Pandemic COVID 19 era (Atmojo \& Nugroho, 2020). EFL teaching-learning assisted technology appears relevant. Therefore, it is necessary to learn and teach persuasive EFL writing with Assisted Technology in prewriting activities as learning strategies. Besides being easy to use, technology can also attract students' attention because of the many exciting applications available in the mobile phone operating system. Teachers can minimize anxiety students make mistakes using digital organizers and community brainstorming. Because of social anxiety-led mental blockage, group brainstorming can affect low productivity. Pre-quality mapping and freewriting are useful. Skill sets could also be used to talk, listen, and learn. Through learning to efficiently and effectively convey thoughts, student writing will become more innovative (OISHI, 2015).

The prewriting activity uses Assisted Technology, namely webbing (Weigle, 2014) or organizing ideas software. Assisted Technology like a spell checker can help them learn to write EFL well (Rimbar, 2017). Also, Alsulami (2016) presented data showing the positive impact of emerging technology in enabling students to learn English. The study focused on seeking ways to encourage students experiencing difficulties in learning English as a foreign language. Results suggest that the use of computer software, social network sites, online video, audio tools, and smartphone and tablet applications indicate student acceptance rates to support language learning.

Research on assisted technology in prewriting in Indonesia, however, is limited. Therefore, this research was examined first, and the student needs analysis while applying a prewriting technique using Assisted Technology in EFL Journalism Writing. Secondly, it recognized assisted technology/tools or applications used, opportunities, and restrictions.

\section{METHOD}

This research is descriptive qualitative research using a case study method. The case study method has gained recognition as a research method. It can be used to build ideas, conceptual models, and theories that are novel yet literature-based. Using qualitative descriptive case studies, the researcher created explanations of the context in which case-enterprises used 
technology. It provided flexibility to discover and explore topics that became important and potentially applicable to the research problem (Ponelis, 2015).

This descriptive qualitative research aimed to propose autobiographical experiences for the needs of teaching EFL Writing using a prewriting strategy (prewriting). It was an activity before students (novice writers) write their writing, with Assisted Technology.

This research was conducted at one of Tangerang's private universities, especially in the English Language Education Study Program. Research participants are seventy-two students as research subjects. These students are in the even semester of the 2019/2020 academic year, then selected purposively. This research is an essential aspect of case studies that require many sources of information, such as questionnaires and interviews (Creswell, 2014).

This research used instruments to obtain data such as questionnaires and structured-written interviews. Data from questionnaires in this analysis are to see field issues. Ponelis also confirmed the interpretation of the study subject's activities to become meaningful (Ponelis, 2015). Furthermore, we gained data by interview to obtain accurate information to analyze the data correctly and systematically.

The researchers built up a self-constructed survey in questionnaires for seventy-two respondents selected from the EFL Journalism class and afterward estimated and assessed subjectively. These instruments are formulated utilizing Google form for cost-adequacy, efficiency, and effortlessness. The sample was purposive sampling. All the while, the interview was written essay form questions. Data are made from the encounters of the respondents about their attitudes and aspirations. Subsequently, this offered data to evaluate their needs: necessities, lacks, and wants EFL Journalism to figure out how to apply prewriting activities with assisted technology. The questionnaires and interviews are based on the Needs analysis approach, Target needs. The student ought to do it in the target circumstance (Nation \& Macalister, 2010). Three viewpoints: the necessities, lacks and wants of understudies to prewriting assisted technology activities were investigated in this study.

Researchers just performed the interview for several respondents to finish the data. The data was interpreted, and the research finding was recorded. In deciding the English language Needs Study, triangulation techniques with different information sources are viewed as significant (Nugraha, 2002). Hence, the triangulation approach is utilized in this analysis.

After the data are collected, the data were reduced and selected. The relevant data are analyzed using the criteria constructed, while the irrelevant data were omitted. The relevant data are arranged into systematic summaries, which are then connected to the literature used. Then, this research was intended to draw the following particular conditions.

a. Analyzing the needs analysis of prewriting activities with Assisted Technology in EFL Journalism writing

b. Examining the assisted technology/tools or applications used, benefits, and constraints found.

\section{RESULTS AND DISCUSSION}

\section{Results}

The data were classified into several units to answer research questions. They were transcribed to be calculated and analyzed manually. Below are the findings. Firstly, the questionnaire was described the data: students' demographics, necessities, lacks, and wants. Secondly, the 
interview depicted assisted technology/tools or applications used, benefits and constraints revealed.

1. The students' demographic data

Table 1

Students' demographic data

\begin{tabular}{llll}
\hline Features & Transcriptions & Frequency & Percent \\
\hline 1.Current Year & Year 2 & 65 & $90.278 \%$ \\
& Year 3 & 7 & $9.722 \%$ \\
\hline 2.Sex & Female & 61 & $84.722 \%$ \\
& Male & 11 & $15.278 \%$ \\
\hline 4.Age Living style & $21-23$ & 61 & $84.722 \%$ \\
& Above 23 & 11 & $15.278 \%$ \\
\hline 5. Internet Access & Home & 67 & $93.056 \%$ \\
& Dormitory & 1 & $1.389 \%$ \\
& Other & 4 & $5.556 \%$ \\
\hline & Yes & 65 & $90.278 \%$ \\
& No & 7 & $9.722 \%$
\end{tabular}

(Source: Prepared by the authors, 2020)

In table 1, the demographic data of 72 respondents who completed the questionnaire shows that most respondents are in the second year of $90.3 \%$. They are dominated by $84.7 \%$ women, only about $15,3 \%$ men. At most $21-23$ years, their age is $84.7 \%$ of the rest, $15,3 \%$ over 23 years. Moreover, most of them live at home, $93.1 \%$, in dormitories, $1,4 \%$, and others only $5,6 \%$. Internet access is owned by around $90.3 \%$ of them and $9.7 \%$ who do not have it.

2. The students' necessities, lacks, and wants in EFL writing using assisted technology in prewriting activities

The data gained from the questionnaire comprises students' opinion on EFL writing and selfrated on English writing, EFL Journalism writing kinds project, students' prewriting activities in EFL Journalism writing, the frequencies for using assisted technology to write English, and the necessity

Table 2

Students' opinion on EFL writing and self-rated on English writing

\begin{tabular}{llll}
\hline Features & Transcriptions & Frequency & Percent \\
\hline 1. Opinion on EFL writing & $\begin{array}{l}\text { It is something } \\
\text { pleasant to do. }\end{array}$ & 54 & $75.000 \%$ \\
& $\begin{array}{l}\text { It is difficult to } \\
\text { begin to write. }\end{array}$ & 18 & $25.000 \%$ \\
\hline 2. Good or bad at English & Good & 8 & $11.111 \%$ \\
writing & Average & 57 & $79.167 \%$ \\
& Bad & 7 & $9.722 \%$
\end{tabular}

(Source: Prepared by the authors, 2020)

Table 2 displays data about students' opinions on EFL writing. Fifty-four respondents, $75 \%$, said EFL writing is pleasant, and 18 respondents, $25 \%$, said it is challenging to start EFL writing. This table also shows that eight respondents, $11.1 \%$, rated themselves as good on EFL writing, 57 respondents, $79.2 \%$, rated themselves as moderate, the rest seven respondents, 9.7\%, rated themselves as bad on EFL writing. 
Table 3

EFL Journalism writing project types

Features
1. Types of project EFL
Journalism writing

\section{Transcriptions}

Editorial Cartoon

Review a Movie

News Story

Advertisement News

Writing a Broadcast

(Source: Prepared by the authors, 2020)

Table 3 presents the frequency data about the type of EFL Journalism writing project. 'Editorial Cartoon' is nine respondents, $12.5 \%$. The 'Review a Movie' is 16 respondents, $22.2 \%$. 'News Story' is 16 with $22.2 \%$. 'Advertisement news' is 13 respondents, $18.1 \%$. Furthermore, the last is 'Writing a Broadcast' 18 with $25 \%$.

\section{Table 4}

Students' prewriting activities in EFL Journalism writing Kinds of prewriting activities when to write Frequency Percent EFL Journalism writing

1. Reading from a piece of web news and summarizing it, then creating an editorial cartoon by a specific application

2. Watching a movie from a particular application and analyze the film by outlining

3. Selecting my photos or taking the new ones and writing a caption

4. Knowing the excellent of my product and surveying the costumers' satisfaction

5. Reading from web news, clipping the news, writing the script, selecting the app to broadcast

$13.889 \%$

(Source: Prepared by the authors, 2020)

Table 4 indicates the types of prewriting activities in EFL Journalism writing. Most respondents chose answers to web activities, namely reading from web news to make an editorial cartoon $12.5 \%$ and writing a $31.9 \%$ broadcast. So the total is $44.4 \%$. The second is $25 \%$, namely watching a movie to write a review movie. $16,7 \%$ chose to take new pictures or selecting ones to write a News story. Furthermore, finally, $13.9 \%$ conducted analyzing the excellent of a product and surveyed before writing Advertisement news.

\section{Table 5}

Using assisted technology to write English and the necessity

\begin{tabular}{lllr}
\hline Features & Transcriptions & Frequency & Percent \\
\hline 1. Ever used assisted technology to write & Yes & 62 & $86.111 \%$ \\
English & No & 10 & $13.889 \%$ \\
\hline 2. It is helpful to learn EFL writing by using & Yes & 71 & $98.611 \%$ \\
assisted technology in prewriting activities & No & 1 & $1.389 \%$
\end{tabular}

(Source: Prepared by the authors, 2020)

Table 5 reveals the frequency of using assisted technology to write EFL. Sixty-two respondents, $86.1 \%$, said they had, and the remaining ten respondents, $13.9 \%$, said they had 


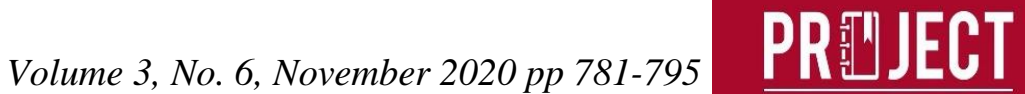

not. It also shows the necessities of assisted technology in prewriting activities. Seventy-one respondents said it was beneficial, and only one respondent, $1.4 \%$, chose the answer no.

\section{The kinds of assisted technology (applications/tools), benefits, and constraints}

The data gained from written structured-interviews. It is depicted about assisted technology (applications/tools), benefits, and constraints as follows.

From the question: "What assisted technology/applications or tools do you use while you are doing your prewriting activities before you begin to write EFL Journalism writing?" some students answered the interview. The researchers revealed many assisted technology/applications or tools respondents applied while doing prewriting activities before writing EFL Journalism. The applications were Google Search/ Google Chrome, Blog, enewspaper, Movie, Google Translate, U-dictionary, Reverso, Spellogram, Grammarly, Grammar Fix, Ginger keyboard, Quillbot, Plagiarism Checker, Microsoft Word, WPS Office, Notes, PhotoGrid, PicsArt, Pinterest, Adobe Illustrator, Speech Bubbles, Voice Recorder, Anchor, Canva, YouTube, Camtasia, and Kinemaster.

The researchers obtained other data: the benefits of prewriting activities using assisted technology in EFL Journalism writing. The question has 'What benefits can you feel in learning EFL writing by using apps or tools/Assisted technology in your prewriting activities before you begin writing EFL writing?' There are numerous answers to do that. However, these various answers have three categories with the same line.

Firstly, the answers association has the same meaning, i.e., helpful. As P\#1 answered, "Well, with the assisted technology/application that I used. It is helping me. Moreover, it makes me more confident." P\#2 added, "It makes my writing activities easier, faster, simpler, and efficient," P\#3 said, "It helps me write English correctly, better in grammar." P\#4 asserted, "We can make three sentences, and from three sentences, we can develop them into threeparagraph by using assisted technology in prewriting activities." Moreover, P\#5 said, "The benefit when I use the application to write is that it makes me easier to find the meaning of new vocabulary that I do not know."

Secondly, besides helpfulness in writing problems, the same answers are about increasing their knowledge, information, ideas, inspiration, intelligence, and creativity to begin writing English. As P\#6 said that, "Using application/ assisted technology helps me to begin writing, and the application also to correct the grammatical." Furthermore, P\#7 answered that "It increases intelligence, creativity in thinking, and encourages the ability to seek and collect information." P\#8 answered, "Using application/ assisted technology helps me begin writing, and the application also corrects the grammatical problems." Moreover, P\#9 added, "It helps me get the ideas to write. The time given by the EFL writing teacher gives me have flexible time to do and edit my writing. And there are many tools to use in the prewriting activities." Thirdly, the answers have the same meaning, namely autonomous learning and creativity. For example, P\#10 said, "We can get more creative and get information easily." P\#11 added, "The benefits that I can feel in learning to write EFL with applications or technology tools, I can find out how to use the application." P\#12 asserted, "The benefits that we can get is more organized. It helps me to write news, summarize, storyboard, etc." P\#13 added, " Using assisted technology in prewriting activities makes me know more experience about EFL based on publishing criticism editorial and how to apply them."

Moreover, P\#14 answered, "The benefits are knowing what applications are suitable for our prewriting, learning to use new applications, be more creative in using it." P\#15 said, "It can make it so easy to post and listen by listeners because it is connected to Spotify as a popular app in this era." Then, P\#16, "I admitted I love this assisted technology. When I use the camera 
Oppo mobile for taking pictures, all pictures look perfect and clear. Then, I edited photos in Canva for writing a caption, News Story."

Furthermore, from the question of "What challenges did you face in learning EFL writing using assisted technology in your prewriting activities before you begin writing EFL writing?" the researchers found the challenges of writing English correctly and improve their English. As P\#1 said, "In writing activities of how to review a movie, it was very challenging to upload our writing on blog because I must be more careful with the words used since I used free Grammarly platform. It is not premium." P\#13 asserted, "Even the assisted technology helps me to write English, but I still doubt the accuracy."

On the other side, there is an answer that the tool is a barrier because the respondents cannot operate the tool. Such as P\#2 answered, "Sometimes I do not know how to use the technology." P\#10 and P\#11 have the same idea that they admitted never to try the tools before, so they could not apply it. P\#12 added, "Sometimes, it does not work if my memory card was full." Another challenge is a terrible internet connection due to signal problems and limited quota data internet as P\#3, P\#4, P\#5, P\#6, P\#7, P\#8, and P\#9 admitted. What to add here is P\#14, $\mathrm{P} \# 15$ and P\#16 believed they found no challenge.

\section{Discussion}

The researchers revealed the students' necessities, lacks, and wants/expectations in learning EFL Journalism writing using assisted technology in their prewriting activities from the data findings, questionnaires, and interviews. The researchers revealed the lack of the students' opinion on EFL writing and self-rated on English writing from the questionnaires. It was found that there are 18 respondents, $25 \%$, felt difficulty in EFL writing and 57 respondents, $79,1 \%$, assumed moderate in EFL writing competence, and seven respondents, 9,7\%, self-rated bad. It is in line with what Álvarez (2020), Ben Maad \& Saadi (2020), Abdullah (2013), Singh \& Maniam (2020) believed that EFL writing teachers face more obstacles that students committed syntactic errors when they wrote. It regards the intercultural dimension of the interferes as the first language to EFL.

Consequently, prewriting activities using assisted technology could fill this gap. It allows EFL writing students to learn EFL writing effectively. By webbing, reading from web news (Weigle, 2014), EFL writing students could get the idea to write. Goris et al. (2020), Abderraouf (2016), Muslim (2014) confirmed this. They said that an essential learning EFL factor is a general interest in other languages and cultures. A sense of identification with speakers of the target language is also essential. Low interest and motivation to learn the target language make the EFL writing students losing motivation to write English. Thus, second or foreign language exposure, such as reading the media, supports the students' EFL skill.

Others lack are the students' usage of assisted technology and the internet problem. The questionnaire disclosed that ten respondents, 13,9\%, admitted never used the assisted technology before, and only one respondent, 1,4\%, said the project did not help him/her. Moreover, the interview revealed that only four said that they had a problem in applying the tools among sixteen respondents. Then, the internet problem data is gain from the interview. The researchers face that seven respondents had bad signal and limited quota data internet. It might be the problem of no internet access at their homes as it shows in the questionnaire that seven respondents selected "No" answer to the internet access at the home question. Thus, the EFL writing teachers as curriculum developers must ask the institution to provide students with adequate server internet and training on assisted technology used in prewriting activities to get used to applying the tools. It is similar to Zhiyong et al. (2020); he believed 
that college EFL teachers should frequently change their teaching plans to find the best address the needs of students.

The questionnaires explored the students' necessities and wants/expectations in prewriting activities using assisted technology in EFL Journalism writing. They are EFL Journalism writing kinds project, students' prewriting activities in EFL Journalism writing, the frequencies for using assisted technology to write English, and the necessity. The researchers found that most of the respondents affirmed the EFL writing kinds project, the prewriting activities, the frequency of usage, and the project's necessity. It is the same with Servati (2012), Weigle (2014) asserted that English writing teachers need techniques to support their initial anxiety, start preparing their ideas, and begin writing. This preparation or prewriting provides further chances for EFL learners to understand the message being written. EFL writers began writing with a plan. These plans lead him to compose, then write down well.

In the interview, it was revealed that the applications or the tools used. The applications were Google Search/ Google Chrome, Blog, e-newspaper, Movie, Google Translate, U-dictionary, Reverso, Spellogram, Grammarly, Grammar Fix, Ginger keyboard, Quillbot, Plagiarsm Checker, Microsoft Word, WPS Office, Notes, PhotoGrid, PicsArt, Pinterest, Adobe Illustrator, Speech Bubbles, Voice Recorder, Anchor, Canva, YouTube, Camtasia, and Kinemaster. A line with Troudi \& A-Mahrooqi (2014) and Engstrom (2005) believed that Assisted technology facilitates effective language-classroom teaching. They include computers/gadgets, fast internet connections, and stable platforms-advanced instructor experience and how these resources help language classes. Teachers can take advantage of developing technology to attract students' attention. Assisted Technology is one-way teachers can teach to help learners learn English language skills. Assisted Technology supports devices or applications such as text-to-speech software, word-processing programs, voice-recognition software, and organizing ideas software. Since EFL teaching-learning ran online in the Pandemic COVID 19 age so that EFL teaching-learning assisted technology becomes an immediate need, as also reported by Atmojo \& Nugroho (2020).

Based on the findings and discussion, the researchers concluded that the result of students' needs analysis of prewriting activities using assisted technology in EFL Journalism writing could be used to develop the curriculum: the syllabus and learning of the EFL Journalism writing course using assisted technology. Thus, it would be more productive so that the learning outcomes would be achieved successfully.

\section{CONCLUSION}

The researchers revealed the students' necessities, lacks, and wants/expectations in learning EFL Journalism writing using assisted technology in their prewriting activities. They found the students' lacks that 18 respondents, 25\%, felt difficulty in EFL writing and 57 respondents, $79,1 \%$, assumed moderate in EPL writing competence. Internet problem data is gain from the interview. Seven respondents had bad signal and limited quota data internet.

The questionnaires explored the students' necessities and wants/expectations in prewriting activities using assisted technology in EFL Journalism writing. The applications were Google Search/ Google Chrome, Blog, e-newspaper, Movie, Google Translate, U-dictionary, Reverso, Spellogram, Grammarly, and Grammar Fix. Teachers can take advantage of developing technology to attract students' attention. Assisted Technology is one-way teachers can teach to help learners learn English language skills. 
The benefits gained from the data interview that students felt it was essential for generating their ideas about a topic before writing. They found that reading web news online resources were sufficient. They also felt it is practical and promote their autonomy to get information about the topic they want to write and write the ideas for their paragraph anytime. Some students experienced no challenges in learning EFL writing.ewriting the ideas for their paragraph anytime, anywhere, so it is useful and makes learning EFL writing pleasantly.

Other constraints are the students' usage of assisted technology and the internet problem. EFL writing teachers should ask the institution to provide students with adequate server internet and training on assisted technology used in prewriting activities. The EFL writing teachers should frequently change their teaching plans to find the best address the needs of students. The researchers face that seven respondents had bad signal and limited quota data internet.

Thus, Assisted technology in EFL prewriting activities allows students to learn and develop their English writing performance. This m-learning can be used anywhere when needed, as writing is a long process and consumes more prolonged effort. EFL writing is essential for EFL students, particularly in universities. Then the assisted technology in students' EFL prewriting attracted the attention of both educators and researchers.

Ultimately, in planning EFL Journalism writing instructional activities, a curriculum developer must provide prewriting activities requiring assisted technology. Usually, in evaluating assisted technology methods, the curriculum developer must include assisted technology to address specific challenges in writing EFL journalism learning. Future use of assisted technology methods to be integrated into lessons should also be considered. Therefore, an appropriate learning and teaching situation can be suggested in EFL Journalism writing instruction with relevant assisted technology tools and relevant learning activities.

\section{ACKNOWLEDGMENTS}

We would like to thank the Research and Community Service (DRPM)-DIKTI for financial support. This study was carried out under the Beginner Lecturer Study (PDP) scheme, 2019. We also appreciate Mr. Imam Muttaqijin and Mrs. Siti Asriah Immawati Rosyid, Research Manager and Deputy Research Manager at Muhammadiyah Tangerang University (LP3M), who provided administrative and technical support during research.

\section{REFERENCES}

Abderraouf, A. (2016). Writing difficulties and common errors in writing: a case study of third year LMD students of English at The University of Bejaia. In University of Bejaia. UNIVERSITY OF BEJAIA.

Abdullah, A. T. H. bin. (2013). Error Analysis on The Use of The SimpleTense and The Simple Past Tense in Writing Essays Among TESL College Students. International Journal of Education and Research, 1(12), 1-12.

Ahmad, J. (2016). Technology assisted language learning is a silver bullet for enhancing language competence and performance: A case study. International Journal of Applied Linguistics and English Literature, 5(7 Special Issue), 118-131. https://doi.org/10.7575/aiac.ijalel.v.5n.7p.118

Al-Gharabally, M. (2015). The Writing Difficulties Faced by L2 Learners and How to Minimize Them. International Journal of English Language and Linguistics Research, 3(5), 42-49. 
http://www.eajournals.org/wp-content/uploads/The-writing-difficulties-faced-by-L2learners-and-how-to-minimize-them.pdf

Alsulami, S. (2016). The Effects of Technology on Learning English as a Foreign Language Among Female EFL Students at Effatt College : An Exploratory Study. CSCanada Studies in Literature and Langauuge, 12(4), 1-16. https://doi.org/10.3968/7926

Álvarez, L. F. C. (2020). Intercultural communicative competence: in-service efl teachers building understanding through study groups. Profile: Issues in Teachers' Professional Development, 22(1), 75-92. https://doi.org/10.15446/profile.v22n1.76796

Ariyanti, A., \& Fitriana, R. (2017). EFL Students' Difficulties and Needs in Essay Writing. Advances in Social Science, Education and Humanities Research (ASSEHR), International Conference on Teacher Training and Education 2017, 158(ICTTE), 111-121.

Atmojo, A. E. P., \& Nugroho, A. (2020). EFL Classes Must Go Online! Teaching Activities and Challenges during COVID-19 Pandemic in Indonesia. Register Journal, 13(1), 4976. https://doi.org/10.18326/rgt.v13i1.49-76

Ben Maad, M. R., \& Saadi, I. (2020). The role of group dynamics in low-achieving EFL students' speaking development. International Journal of Applied Linguistics (United Kingdom), 30(2), 264-279. https://doi.org/10.1111/ijal.12279

Brown, H. D. (2007). Teaching by Principles. An Interactive Approach to Language Pedagogy. In Longman (Third). Pearson Education, Inc.

Creswell, J. W. (2014). Research Design: Qualitative, Quantitative, and Mixed Methods Approaches (V. Knight, J. Young, K. Koscielak, B. Bauhaus, \& M. Markanich (eds.); 4th ed.). SAGE Publications, Inc.

Darmi, R., \& Albion, P. (2014). A Review Of Integrating Mobile Phones For Language Learning. Proceedings of the 10th International Conference on Mobile Learning 2014, ML 2014, 93-100. https://pdfs.semanticscholar.org/754a/f054a2f15bf6d932dd43731bf165b77b2bfa.pdf

Dwivedi, R. S., \& Chakravarthy, R. Vn. (2015). Problems Encountered By Rural Students in Writing English - Role of English Teacher - Some Solutions. International Journal on Studies in English Language and Literature (IJSELL), 3(7), 27-38. www.arcjournals.org

Engstrom, E. U. (2005). Reading, Writing, and Assistive Technology: An Integrated Developmental Curriculum for College Students. Journal of Adolescent \& Adult Literacy, 49(1), 30-39. https://doi.org/10.1598/jaal.49.1.4

Eyerci், A., \& ÇİMEN, B. A. (2017). EFL Students' Perceptions towards Blogging in EFL Writing Courses: A Turkish University Context. Journal of Education and Practice, 8(Special Issue for ICANAS), 100-105.

Fithriani, R., Rafida, T., \& Siahaan, A. (2019). Integrating Online Blogging into EFL Writing Instruction: Exploring Students' Perceptions. Advances in Social Science, Education and Humanities Research (ASSEHR), UNNES International Conference on English Language Teaching, Literature, and Translation (ELTLT 2018), 188(Eltlt 2018), 87-90. https://doi.org/10.2991/eltlt-18.2019.17

Fonseca, K. A. B., \& Peralta, F. S. (2019). Google Classroom: An Effective Virtual Platform to Teach Writing in an EFL Composition Course. International Journal of English Language Teaching, 6(1), 27-35. https://doi.org/10.5430/ijelt.v6n1p27 
Goris, J., Denessen, E., \& Verhoeven, L. (2020). Determinants of EFL learning success in content and language integrated learning. Language Learning Journal, O(0), 1-16. https://doi.org/10.1080/09571736.2019.1709886

Green, T. (2005). Reaching Out to Families : Parental Participation Using Technology To Help English Language Students Develop Language Skills: A Home and School Connection. MULTICULTURAL EDUCATION, Winter, 56-59.

Hidayati, N., Zubaidah, S., Suarsini, E., \& Praherdhiono, H. (2019). Examining the Relationship between Creativity and Critical Thinking through Integrated Problem-based Learning and Digital Mind Maps. Universal Journal of Educational Research, 7(9A), 171-179. https://doi.org/10.13189/ujer.2019.071620

Khvilon, E., \& Patru, M. (2002). Information and Communication Technologies in Teacher Education. A Planning Guide. Allen, Nancy Anderson, Jonathan Davis, Niki Muranov, Alexey Thomas, Lajeane Uvarov, Alexander.

Marek, M. W. (2014). The integration of technology and language instruction to enhance EFL learning. The Technology-Enhanced Language Learners Special Interest Group (TELLSIG) Conference, Providence University, Taichung, Taiwan on 5 June 2014. https://files.eric.ed.gov/fulltext/ED545477.pdf

Mullamaa, K. (2006). ICT in Language Learning - Benefits and Methodological Implications ProQuest. 3(1), 38-44. http://search.proquest.com/docview/821695700/7810B639D95D46B2PQ/1?accountid=4 7253

Muslim, I. M. (2014). Helping EFL Students Improve their Writing. International Journal of Humanities and Social Science, 4(2), 105-112.

Nation, I. S. P., \& Macalister, J. (2010). Language Curriculum Design. In E. Hinkel (Ed.), Routledge (First, Vol. 72, Issue 9). Routledge, Taylor \& Francis Group.

Nugraha, M. (2002). Triangulation of Instrumentation and Data Source: a Stronger Method in Assessing English Language Needs. K@ta: A Biannual Publication on the Study of Language and Literature, 4(2), 148-159. https://doi.org/10.9744/kata.4.2.148-159

Nunan, D. (2003). Practical English Language Teaching (D. Nunan (ed.); First edit). Mc Graw Hill.

OISHI, T. (2015). Applying brainstorming techniques to EFL classroom. NII Electronic Library Service, 121-127.

Ponelis, S. R. (2015). Using interpretive qualitative case studies for exploratory research in doctoral studies: A case of information systems research in small and medium enterprises. International Journal of Doctoral Studies, 10, 535-550. https://doi.org/10.28945/2339

Rimbar, H. anak. (2017). The Influence Of Spell-Checkers On Students' Ability To Generate Repairs Of Spelling Errors. Journal of Nusantara Studies (JONUS), 2(1), 1-12.

Sartini, S. (2020). Kahoot in Maritime English Teaching: Its Impact on Nautical Science Cadet's Oral Reproduction and Vocabulary. English Language Teaching Educational Journal, 3(1), 41-51. https://doi.org/10.12928/eltej.v3i1.1667

Servati, K. (2012). Prewriting Strategies and their Effect on Student Writing How has open access to Fisher Digital Publications benefited you? Fisher Digital Publications. St. John Fisher College. 
Singh, A. K. G., \& Maniam, M. (2020). A Case Study on the Influence of First Language Syntax ( L1 ) in Writing English ( L2 ) Essays among Form Two Secondary Students. Universal Journal of Educational Research, 8(7), 2914-2920. https://doi.org/10.13189/ujer.2020.080719

Solagha, O. Z. (2013). Writing Difficulties in the Swedish ESL-Classroom Writing Difficulties in the Swedish ESL-Classroom. Stockholm Universitet.

Tabari, I. G., \& Tabari, A. G. (2014). Application of computer and technology in EFL syllabus design. Journal of Language Teaching and Research, 5(2), 376-381. https://doi.org/10.4304/j1tr.5.2.376-381

Troudi, S., \& A-Mahrooqi, R. (2014). Using Technology in Foreign Language Teaching. In R. Al-Mahrooqi \& S. Troudi (Eds.), Using Technology in Foreign Language Teaching (First Edit, $\quad$ pp. 1-7). Cambridge Scholars Publishing. https://books.google.com/books?id=NeOmBgAAQBAJ\&pgis=1

Weigle, S. C. (2014). Considerations for Teaching Second Language Writing. In M. CelceMurcia, D. M. Brinton, \& M. A. Snow (Eds.), Teaching English as a second or foreign language (4th Editio, pp. 222-237). National Geographic Learning, HEINLE Cengage Learning.

Zhiyong, S., Sidhu, G. K., \& Muthukrishnan, P. (2020). College english language teaching reform and EFL teachers' teaching practice: A case study in China. Universal Journal of Educational Research, 8(1), 230-237. https://doi.org/10.13189/ujer.2020.080128

Zou, D. (2020). Gamified flipped EFL classroom for primary education: student and teacher perceptions. Journal of Computers in Education, 7(2), 213-228. https://doi.org/10.1007/s40692-020-00153-w 